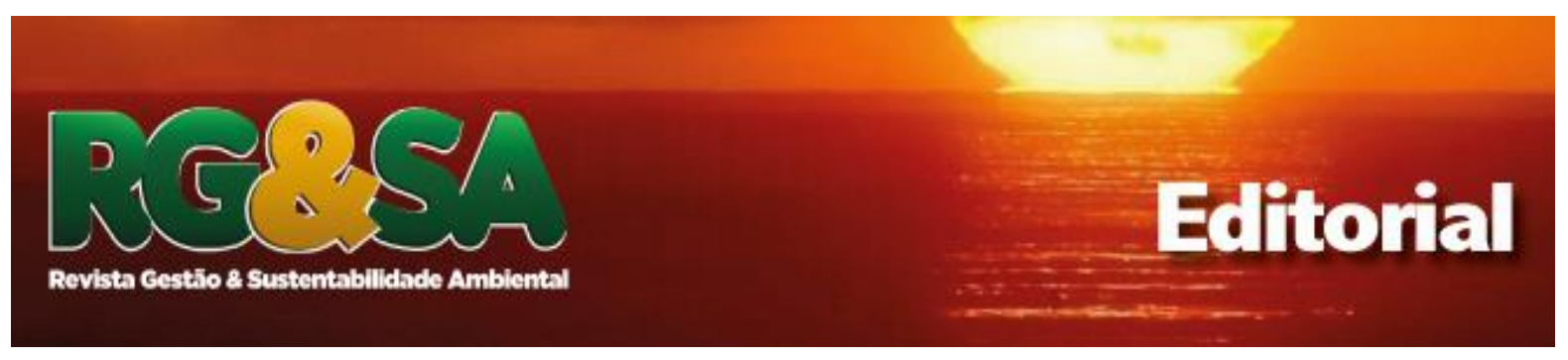

\title{
A PESQUISA NÃO PODE PARAR, ESPECIALMENTE EM ÉPOCAS DE CORONAVIRUS
}

\section{Jairo Afonso Henkes ${ }^{1}$}

Ao se iniciar o nono ano de publicações ininterruptas a Revista Gestão \& Sustentabilidade Ambiental, tem boas razões para comemorar, pois foram anos de intensas trocas e contribuições científicas e crescimento em experiências e expertises, construções coletivas, elaboração de projetos e equipes em redes de pesquisas e provedores de conteúdos relacionados as temáticas da sustentabilidade ambiental.

Desde o princípio esta revista tem oportunizado a abertura de oportunidades para a divulgação e socialização de novos conhecimentos, tornando-se uma publicação com excelente qualificação de seus conteúdos. Neste período de pandemia na área de saúde, por conta da pandemia provocada pelo coronavirus, a produção científica, através do trabalho de centenas de pesquisadores, acadêmicos e autoridades do setor, não pode parar, assim como sua publicação, para que sempre se mantenha a opinião pública a par dos acontecimentos e da evolução da ciência.

Nossa área de atuação tem relevância na gestão e controles de eventos desta natureza, pois de fato abarca conhecimentos fundamentais na área de educação ambiental, na sanidade dos ambientes e na sustentabilidade ambiental, que sempre vai nos garantir melhores condições de reverter esta e outras epidemias ou pandemias.

Destaca-se a relevância dos temas tratados e debatidos nesta edição que trazem à discussão diversas situações que devem ser discutidas e compartilhadas, para que possam ser aplicadas na solução de problemas relacionados à gestão de crises das mais diversas, quer elas tenham cunho de saúde, econômico ou socioambientais, em nosso dia a dia. 
Nesta edição em que iniciamos o nono ano de plena circulação, sediados no Portal de Periódicos da Unisul, no link:

http://www.portaldeperiodicos.unisul.br/index.php/gestao ambiental

apresentam-se vinte e três artigos que abordam questões relativas à gestão de recursos hídricos, bacias hidrográficas, gestão de resíduos, logística, sustentabilidade de ambientes protegidos, resíduos na aviação, sustentabilidade em aeroportos, gestão ambiental na geração de energia e suas conexões, a água enquanto promotora da saúde pública, a gestão da sanidade ambiental e a produção limpa.

Enfocam-se nela também as novas tecnologias e estratégias de melhoria contínua, para a reprodução de meios e atividades que movem as forças e relações que impactam nosso ambiente, em especial neste momento de grandes preocupações mundiais em face à pandemia da Covid19 em pleno curso, com seus efeitos presentes no dia a dia em todo o planeta.

De acordo com a tradição deste periódico científico, publica-se também nesta edição onze estudos de caso, que debatem importantes temáticas que permitem ampliar o debate e aprofundar as análises sobre diferentes temas. Este espaço pretende promover o aperfeiçoamento científico, transversal e interdisciplinar para solucionar os problemas complexos, identificar suas causas e controlar suas consequências.

Constitui-se missão deste periódico, interagir e socializar o conhecimento sobre as diversas estratégias nos segmentos público ou privado que se inserem no contexto da saúde ambiental e que são fundamentais para a busca de um ambiente mais sustentável.

Este periódico científico, de ampla circulação e acesso gratuito, conta com publicações trimestrais, com edições ordinária e especiais, sendo que neste ano contará com duas edições especiais, originadas do Simpósio Mundial de Sustentabilidade, uma já publicada e a próxima a ser publicada ainda neste semestre.

1 Doutorando em Geografia (UMinho-Pt). Mestre em Agroecossistemas (UFSC). Especialista em Administração Rural (UNOESC). Engenheiro Agrônomo (UDESC). Professor do Curso de Administração, do Curso Superior de Tecnologia em Gestão Ambiental e do Programa de Pós Graduação em Gestão Ambiental da Unisul. E-mail: jairohenkes333@gmail.com 